\title{
Using Technology to Engage Preservice Elementary Teachers in Learning about Scientific Inquiry
}

Loretta L. Jones, ${ }^{\star 1}$ James R. MacArthur ${ }^{2}$ and Sevil Akaygün ${ }^{3}$

Elementary teachers are often required to teach inquiry in their classrooms despite having had little exposure to inquiry learning themselves. In a capstone undergraduate science course preservice elementary teachers experience scientific inquiry through the completion of group projects, activities, readings and discussion, in order to develop a sense of how inquiry learning takes place. At the same time, they learn science content necessary for teacher licensure. The course exposes students to different pathways of scientific discovery and to the use of the computer both as a tool for conducting inquiry-based investigations and as a means of collecting and sharing student opinions. The students involved have many misconceptions about science and it is often difficult for them to distinguish science from pseudoscience. Computer simulations are used to help students understand that difference. In addition, a classroom response system using "clickers" is used to poll student opinions on controversial issues and to stimulate discussion.

Key words: Classroom response systems, Clickers, Elementary science education, Scientific inquiry, Technology

\section{Introduction}

The introduction of inquiry-based activities into the science curriculum resulted from a desire in the mid-twentieth century to engage students in the process of science (DeBoer, 1991). Traditionally, science had been taught as a series of facts, often poorly connected to 
one another. By engaging students in inquiry activities, the students can appreciate the thought processes of scientists and design their own experiments. Several definitions of inquiry are in use (Flick \& Lederman, 2006; Minner, Levy \& Century, 2009; Novak, 1964). However, a common definition in the United States is that published by the National Research Council:

Inquiry is a multifaceted activity that involves making observations; posing questions; examining books and other sources of information to see what is already known; planning investigations; reviewing what is already known in light of experimental evidence; using tools to gather, analyze, and interpret data; proposing answers, explanations, and predictions; and communicating the results. Inquiry requires identification of assumptions, use of critical and logical thinking, and consideration of alternative explanations. (NRC, 2000, p. 14)

Most elementary teachers in the United States are now required to use inquiry activities in science lessons (Crawford, 2000; Flick \& Lederman, 2006; National Research Council, 2000). In order for teachers to be successful in the use of science inquiry experiences in their own classrooms they need to experience inquiry in their own learning of science (Gitlin, Barlow, Burbank, Kauchak \& Stevens, 1999; Haefner \& Zembal-Saul, 2004; Howes, 2002; Jones, Buckler, Cooper \& Straushein, 1997; Windschitl, 2002). However, most preservice teachers (those in teacher education programmes) have had little experience learning with inquiry (Gabel, 2003; Millar \& Lubben, 1996; Newman, Abell, Hubbard, McDonald, Otaala, \& Martini, 2004).

Not only is an understanding of the process of science necessary in order to teach inquiry skills, teachers also need to have sufficient understanding of science content (Luera \& Otto, 2005). Preservice teachers may have misconceptions about science and may not be able to distinguish science from pseudoscience (Cochran \& Jones, 1997; Nelson, 2000). Therefore, it appears that preservice teachers will be best prepared to teach science by inquiry if they have learned inquiry in a science context.

Although many teachers have to use technology in their classrooms, preservice teachers are often uncomfortable with technology and avoid using it (David \& Falba, 2002). Introducing technology into science method courses and science courses for elementary teachers 
has been found to encourage teachers to use technology in their own classrooms (Kim, Hannafin \& Bryan, 2007). The present article reports on a capstone science inquiry course that integrates technology in meaningful ways in order to prepare teachers to lead students in inquiry-based activities and to help them distinguish science from pseudoscience. In addition, the use of technology to help students navigate the interface of science and personal beliefs is described.

\section{Theoretical background}

Inquiry-based learning is thought to provide students with authentic learning experiences that develop deeper understanding due to their constructivist nature (Flick \& Lederman, 2006). In a review of 18 years of research on learning, Minner, Levy, and Century (2009) found that in the majority of the studies inquiry-based education had a positive effect on the learning of science content and on the development of inquiry skills, particularly when students were actively engaged. Because time and consistent effort is required to build competence in inquiry and productive inquiry communities (Šimenc, 2008), it may be important for teachers to have had multiple inquiry experiences before beginning their teaching careers.

One aspect of inquiry learning thought to be beneficial is the observation that different learning styles can easily be accommodated in inquiry-based learning activities (Oblinger \& Oblinger, 2005). Learning styles are the various ways of learning preferred by an individual depending on his or her ability, interest or individual preferences. Fleming (1995) classified learning styles in his VARK model (Visual, Aural, Read/Write, and Kinesthetic/Tactile). In this model visual learners prefer seeing visualizations such as pictures, drawings, diagrams, or simulations when they learn. Auditory learners prefer to learn through listening to lectures, discussions, or tapes. Students who learn the best when they read or write fall into the reading/writing group. Kinesthetic/tactile learners prefer to learn through active experience and movement. Including multiple modes of learning in a lesson has the potential to maximize learning because students with different learning styles may benefit from the different representations (Sims \& Sims, 1995). Inquiry-based science teaching has also been found to motivate students with different learning styles to learn science (Tuan, Chin, Tsai \& Cheng, 2005). 
The use of technology in the classroom has been found to enhance learning by allowing students to view visualizations of phenomena not otherwise visible (Ardac \& Akaygun 2004; Kelly \& Jones, 2007), to provide feedback on understanding (Jones \& Smith, 1993), and to assess student learning (Ferk, Vrtacnik, Blejec \& Gril, 2003). Technology can also be used to enhance inquiry learning (Edelson, Gordin \& Pea, 1999). Classroom response systems using small, hand-held devices commonly known as "clickers" provide a means to enhance interactions in the classroom. These devices contain a keypad and, when used by students, emit either infrared or radiofrequency radiation signals that are collected by an instructor. The technology provides the instructor with immediate feedback on student understanding. This technology is considered by the US National Research Council to be a positive trend in education (NRC, 200oa). In science courses clickers have been used for formative assessment, to foster student collaboration, to give quizzes, to allow anonymous responses, and to take attendance (MacArthur \& Jones, 2008).

\section{Course design}

To introduce preservice elementary teachers to scientific inquiry, a capstone science course in scientific inquiry was developed at the University of Northern Colorado (Fortino, 2003; Taber \& Quadracci, 2006). The course was designed so that students would learn about inquiry in science classes while conducting their own group inquiry activities. Opportunities are provided for them to enhance their own inquiry skills, to develop the ability to evaluate and revise inquiry activities developed by others, and to design and present their own inquiry activities. Classes are held in a room designed for the science education of elementary teachers (Figure 1). 


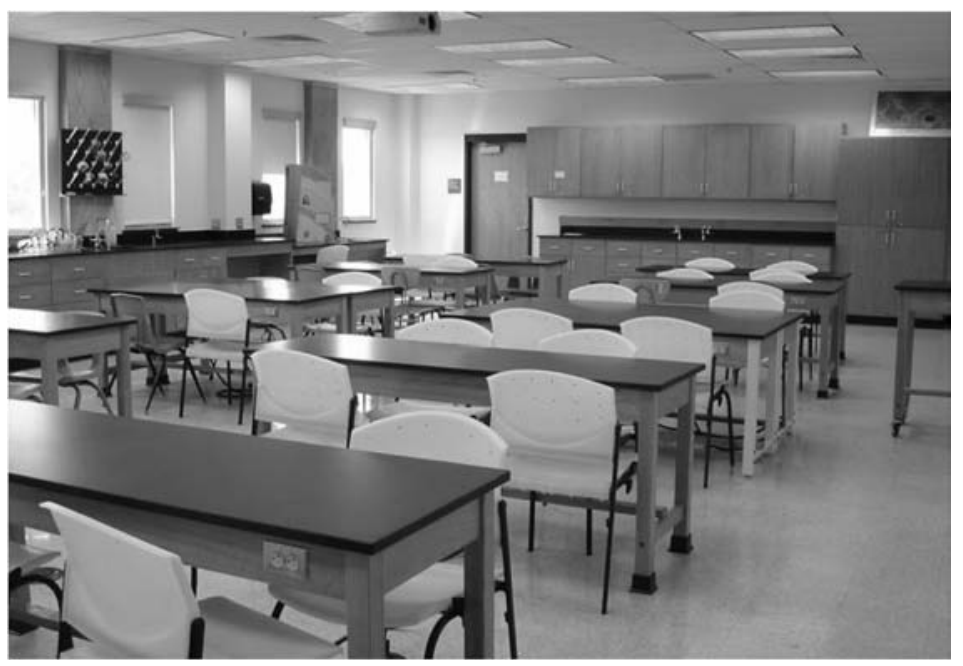

Figure 1. The classroom devoted to the science education of elementary teachers contains tables for group learning. Laboratory and lecture are integrated and take place in the same room. The room has an additional preparation area and a storage room for 20 laptop computers and other equipment.

At the University of Northern Colorado students who want to be licensed to teach in elementary schools major in Interdisciplinary Studies, Liberal Arts (IDLA). Students take a core set of courses and select an emphasis area, such as social studies, English or chemistry. All IDLA students must complete an elementary methods course with a six-week science portion. They must also complete three introductory science courses. Although students have several choices, most take the three courses (physical science, biology and earth science) that have been developed especially for elementary teachers (McDevitt, Troyer, Ambrosio, Heikkinen \& Warren, 1995). Each of these science courses has a laboratory component that incorporates some inquiry experiences. The capstone science inquiry course is taught by science education faculty members from all of the science departments. About 150-240 students per year enroll in the course, which is taught in sections of about 30 students each.

The goals of the scientific inquiry course are to engage students in examining science as a "way of knowing," to help them to develop a sense of "how I learn by inquiry," to enhance their understanding of the interrelationships between scientific discovery and society, to develop a portfolio of inquiry teaching resources, to learn more about 
using computers as a tool for conducting inquiries, and to learn science content required for licensure in the State of Colorado. The course is a science course in which students learn scientific content, rather than a methods course. However, an attempt is made to engage students in activities that they can use later in their own classrooms.

The criteria for inquiry used in the course were based on criteria recommended by the US National Academy of Sciences (National Research Council, 2000):

Students must:

- be actively involved in a hands-on activity or simulation

- formulate questions

- $\quad$ make and check predictions

- design and carry out investigations

- $\quad$ collect, analyse, and explain data

- manipulate variables

- $\quad$ report results and compare them with accepted facts

- develop scientific reasoning skills

- be stimulated to learn more

Various textbooks have been used in the course. Common selections are books by Derry (1999) and Bryson (2003). These books examine the nature and process of science and include science content that goes beyond what students have learned in their introductory science courses.

Students learn the science content as they work in groups to complete activities in earth science (plate tectonics, earthquakes, volcanoes, geologic time, climate), physics (energy, atomic structure, the electromagnetic spectrum), chemistry (the periodic table, chemical reactions, the nature of matter), and biology (the diversity of species, natural selection). About $60-70 \%$ of class time is spent on learner-centred activities such as hands-on paper or laboratory activities, computer activities, or group discussions. Because students are seated at tables of four or five students each, discussion normally takes place within each table group.

Each faculty member teaches the course with his or her own preferences and innovations. This paper focuses on the introduction of two types of technology-based innovations: the use of online materials and simulations to facilitate inquiry and to help students distinguish science from pseudoscience, and the use of a classroom response system to allow students to share personal views anonymously for later discussion. 


\section{Types of inquiry activities implemented}

Several kinds of activities were designed for the capstone science course: laboratory activities, hands-on activities using paper or other objects, discussion and written reports, computer-based simulations, learning to use online research tools, and sharing and communication on the Blackboard course management system (http://www. blackboard.com/Markets/Higher-Education.aspx).

Each activity has inquiry components and students are asked to rate the inquiry components of each activity they complete. Initially students are asked to devise their own inquiry criteria. However, students in this type of course benefit from having detailed rubrics (Newman et al., 2004). Therefore, after comparing and discussing their ideas, students are given Table 2-6, "Essential Features of Classroom Inquiry and Their Variations," from Inquiry and the Science Education Standards (NRC, 200o, http://www.nap.edu/openbook.php?record_id $=9596 \&$ page $=29 \#$ p200165cc9960029001). This table lists five aspects of inquiry (posing questions, using scientific evidence, formulating explanations, connecting explanations to scientific knowledge, and justifying the explanations) and provides four levels of student independence, ranging from teacher-directed activity to learner-generated activity. Students are expected to be able to use the concepts in this table to rate the inquiry level of activities in examinations and in their subsequent teaching assignments. In order to prepare students for this type of authentic task the day after the students have performed each activity they are asked to discuss how well the activity fit each of the essential features and to rate the activity.

Most assessments in the course are authentic activities that teachers often perform, such as evaluating the inquiry characteristics of an activity, modifying an activity to enhance its inquiry characteristics, and designing inquiry activities. However, multiple-choice questions on the science content are also included in the examinations.

Hands-on laboratory activities vary by instructor, but in the version of the course described here they include the generation of gases and the synthesis of polymers. Other hands-on activities include the classification of rock samples and prediction of the design on the bottom of a cube from clues on the visible sides (for an example, see http://brainu.org/inquiry-cubes). After working on inquiry activities in class, students are given descriptions of science activities for elementary school children and are asked to revise the activities to enhance 
their inquiry characteristics. In order to understand scientific thinking processes students model those processes. For example, they are asked to generate a periodic table of "aliens" using methods similar to those used by Mendeleev. (See http://www.gk12.ilstu.edu/New/lesson_template.asp?lessonID=402). In this activity, pictures of aliens who have landed on Earth are sorted according to characteristics such as number of fingers and body shape. One alien is missing and students must predict its appearance.

\section{Fostering engagement in scientific inquiry with technology}

Computer simulations offer many advantages for this type of instruction. Because data can be collected and analysed quickly, students can carry out many experimental trials, more closely modelling the processes of expert scientists. Although only some of the activities are simulations in which students can manipulate the variables, they provide an introduction to an aspect of science that might not be possible in a setting where experiments can be conducted only once. For example, students use sophisticated software such as WorldWatcher (http://www.geode.northwestern.edu/softwareWW.htm) to conduct in-depth inquiry investigations (Taber \& Quadracci, 2006).

Another online activity that engages students in scientific inquiry is designing a planet (see http://astroventure.arc.nasa.gov/DAP/ index.html). In this activity groups of students use a simulation to design a habitable planet for humans by selecting appropriate characteristics such as type of star, distance from the star, availability of liquid water and the producers on the planet. After they finish designing the planet students receive immediate feedback from the programme on whether their planet is habitable or not. They then examine with their group members how to improve their planet. This type of computerbased activity engages students in learning by inquiry because the simulation guides them in questioning, predicting, reasoning, thinking critically, and applying and evaluating their understandings.

In general, most classroom science activities emphasise visual, auditory, and reading/writing aspects, rather than kinaesthetic/tactile aspects. However, access to materials on the Internet has facilitated the introduction of activities that appeal to kinaesthetic/tactile learners. One example is the activity "Kinaesthetic Astronomy" (see http:// education.sdsc.edu/teachertech/downloads/kin_astronomy.pdf). 
In Kinaesthetic Astronomy students experience basic astronomical concepts such as the meaning of day, year and season through bodily movements and positions such as rotating, spinning and walking. This activity helps students improve their reasoning skills as they physically imitate the motions of the Earth and moon and connect their observations with these motions.

The Internet plays an important role in the course. Blackboard is used for online quizzes, discussion, resources, surveys and web links. Students also learn to access the National Science Digital Library (http://www.dlese.org) to search for science lessons with appropriate levels of inquiry characteristics.

The Internet is also used by students to complete assignments on the interface of science and personal beliefs. One example is an activity that helps students to distinguish science from pseudoscience. Many of the students in this course have some belief in pseudoscience. This activity presents them with what appear to be on-line occult happenings that they must find a way to explain. Extrasensory perception (ESP) was selected as an example of how easy it is to be fooled by pseudoscience. Initially, students visit a website that claims it can read their minds (for example, see http://sprott.physics.wisc.edu/pickover/esp.html), and develop in groups an explanation of how the ESP program tricks the viewer. They then design experiments to test their explanation. This activity helps students to face personal beliefs that may conflict with scientific knowledge.

Students learn to use the computer as a tool. Because communicating ideas is an important inquiry skill, each student group must research and prepare a Powerpoint presentation on a scientific discovery of their choice and present it along with a related hands-on activity that they have devised or that they found on the Internet. Peer review is used to give students practice in the assessment of presentations and activities.

\section{Fostering engagement with a classroom response system}

When a classroom response system utilizing clickers to solicit student input and feedback is used in science courses, typically groups of students are given a problem to solve. The instructor then projects a histogram of the responses, after which students can discuss the findings and revise their answers (Fagen, Crouch \& Mazur, 2002). In the

science inquiry capstone course clickers were used in a different way. 
The concepts covered in the course often do not have answers that can be scored objectively. Instead, the scoring of student responses is based more on their ability to justify a response than the response itself. Clickers were introduced into the scientific inquiry capstone course to facilitate the following three processes:

- To rate the inquiry aspects of an activity.

- $\quad$ For anonymous polling of opinions on controversial topics.

- To review for the final examination.

\section{Rating the inquiry aspects of an activity}

When students rate an activity that they have completed the previous day they use clickers to vote on their rating of each aspect of inquiry, as described previously. After the histogram for each aspect is displayed, volunteers who have made each of the more popular ratings are called upon to defend their choices, leading to further discussion. Without clickers the discussions took place in individual groups. Although the groups reported their ratings, it was difficult to determine the majority opinions.

\section{Anonymous polling of opinions on controversial topics}

Because the capstone course deals with societal issues, the interface of science and religion and topics such as evolution, which are not accepted by some students, clickers allow students to share their true opinions without fear of peer rejection or being "punished" by the instructor for a dissenting opinion. Students are asked to respond to questions such as those in Figure 2. Following the voting the class discusses the responses. 


\begin{tabular}{|l|}
\hline $\begin{array}{l}\text { Derry says "Science attempts to bring coherence } \\
\text { to our experiences, whereas religion attempts } \\
\text { to infuse our experiences with meaning." }\end{array}$ \\
\hline Do you think this is a fair statement? \\
\hline a) $\quad \begin{array}{l}\text { Yes, I think this statement is fair to both science and } \\
\text { religion. }\end{array}$ \\
\hline $\begin{array}{l}\text { No, I think this statement overstates the importance of } \\
\text { science and understates the importance of religion. }\end{array}$ \\
\hline c) \begin{tabular}{l} 
Noligion and understates the importance of science. \\
\hline d) $\quad$ I am not sure what this statement means.
\end{tabular} \\
\hline e) $\quad$ Other (please be prepared to explain.) \\
\hline
\end{tabular}

Figure 2. Sample clicker question on a topic from the assigned reading.

Clickers are particularly useful when students are learning about pseudoscience and the belief in the intelligent design of the universe held by some. This application is felt to be important because the students will be classroom teachers and may have in their class students whose parents believe in intelligent design or aspects of pseudoscience.

\section{Reviewing for the final examination}

In the terms during which these innovations were introduced, $20 \%$ of the final examination consisted of 25 multiple choice questions, some of which had more than one correct answer. The mid-term examination students had taken did not contain this type of question. Therefore, in order to prepare students for the final examination one day of the course was set aside as a review day, in which a large portion of the class time was spent using clickers to answer a series of eight multiple choice questions similar in nature to those that might appear on the final exam. These questions covered a wide variety of material discussed in the course: activities performed, significant scientific discoveries, scientific concepts such as experimental design and proportions, and aspects of scientific inquiry. Students voted individually on their selection for each question, followed by a classroom discussion. 


\section{Course evaluation}

The course as a whole was evaluated by the 29 students in one class. The students were provided two opportunities to evaluate the course: an anonymous online survey midway through the term and an anonymous open-ended written survey to evaluate the activities, course materials and instructional approaches at the end of the term. In addition, the authors of this paper (two of whom were instructors and one who served as a faculty observer and attended the majority of the class sessions) recorded their experiences with clickers and identified any difficulties that had arisen with their usage.

\section{Evaluation results}

Reactions to the activities, course materials, and instructional approaches

Throughout the course students had experienced inquiry via various activities, discussions, readings, and assignments. The openended course survey completed at the end of the term showed that when students were asked what aspect of the course they enjoyed the most, they identified the nature of inquiry in their group work (33\%) activities (29\%), hands-on experiments (15\%), computer activities $(15 \%)$, inquiry (4\%), and readings from Derry (4\%). In other words, they said they enjoyed inquiry in different ways. Twenty-two percent of the preservice elementary teachers also voluntarily mentioned that they would consider implementing some of these activities in their own teaching.

Some of the student responses to the question, "What aspects of this course did you enjoy the most?" are given below.

- "I enjoyed the scientific inquiry."

- $\quad$ "I really like being able to work in groups and share

information as a group. I like how science is taught in a simple way that is understandable."

- $\quad$ "I enjoyed all of the activities we did; they will be very helpful in my future classroom"

- $\quad$ "I really enjoyed all of the activities and resources of sites that were interactive for children. I feel as though I will refer to them when I become a teacher and that they will be useful when I teach anything science related!"

- $\quad$ "I enjoyed the online inquiry activities the most because they were hands-on". 
- "The aspects that I enjoyed the most were the computer-based activities. They were fun, interactive, and I look forward to integrating them into my future classroom".

When the students were asked which aspects of the course they found the most useful, they mentioned the in-class activities (35\%), using the inquiry table for evaluating the inquiry nature of the activities (19\%), modifying activities to be more inquiry oriented (15\%), learning inquiry, the computer/online activities (8\%), the experiments (4\%), the readings (4\%), and learning the National Science Education Standards (4\%). It should be noted that these comments were generated by the students. Therefore, although the percentages are small, they represent spontaneous comments from students. Overall, students made positive comments on each question.

Some of the student responses to the question, "What aspects of this course do you find the most useful?" include the following:

- "The inquiry in this course was very important and useful for me because I hadn't known anything about it until I took this course. I feel like it will help me make decisions about my lesson plans when I become an elementary teacher."

- "I think knowing and understanding scientific inquiry will be very useful for me as a future teacher."

- $\quad$ "I thought the activities that we could use in an elementary school setting (like the activity with the aliens that we had to categorise) were most helpful."

- "The inquiry table was helpful/useful."

- $\quad$ "The ideas for how to make activities more student oriented and less teacher oriented. In some activities students need to have more interaction so they will be able to learn better."

- "The aspect that I found most useful is making science activities more inquiry based."

\section{Reactions to the use of clickers}

Students provided positive feedback regarding the use of technology in general and clickers specifically, in both the online survey and the in-class written evaluation, even though there were no questions specifically about technology on either evaluation. One of the questions in the online survey was: "I'd like to have a more active class discussion in lectures. Do you have any suggestions on how to facilitate this?" A student response to this question was: "I think that discussion 
with the groups is good. Like when we use clickers and we have to answer the questions as a group." When asked at the end-of-term evaluation to provide an example of something the instructor did well, several students mentioned the use of technology, and one student said "I liked how the instructor used clickers."

\section{Instructor reactions to the use of clickers}

The clickers were found to be especially useful in eliciting opinions on controversial topics from students. The anonymity of clicker input allowed students to express themselves freely. For example, in a lesson on evolution clickers were used to discover that some students did not believe in evolution. Following the lesson these students retained their beliefs, but because they had been allowed to express their ideas, they did not feel it necessary to continue arguing their points. However, clickers were found to be less useful for activities such as examination review, which could be easily conducted without them. The use of clickers was found to have some drawbacks. It takes class time to implement the technology, students may have difficulty adjusting to the unfamiliar interaction, the technology may not work properly, the format of questions is usually limited to multiple-choice, and it may take additional time to adjust lesson plans to the technology. Despite these difficulties, the technology was found to be valuable and worth using again.

\section{Conclusions}

Throughout the course students experienced inquiry via various activities, projects, discussions, readings, and assignments. The students found the inquiry-based activities to be both useful and enjoyable. The observation that students responded positively to each question of the final course survey suggests that these preservice elementary teachers felt that they learned, appreciated and evaluated inquiry in the course activities, and wanted to include inquiry in their lesson plans when they start teaching.

It was possible to expand the inquiry experience through the use of technology. Computers were used to engage students in simulated inquiry experiences not otherwise possible in a classroom. Students also learned how to use the Internet as a tool for designing their own inquiry learning experiences.

The use of clickers allowed instructors to introduce more 
activities consistent with the theme of student empowerment. Others have concluded that student empowerment is an essential feature of successfully implementing clickers into classrooms (Trees \& Jackson, 2007). For example, students used clickers to rate the inquiry aspects of activities. The ratings themselves were not as critical as the justifications for their selection, which led the students into a discussion regarding their choices. Perhaps even more empowering was the use of clickers to poll students on their opinions regarding the interaction between science and religion. Students were allowed to express their feelings completely anonymously, as instructors had no record of which clicker each student was using. The use of clickers also allowed instructors to clarify some points of confusion with the reading, as students often chose "I am not sure what this statement means" when provided with the opportunity to state their opinion on an excerpt from the text.

The implementation of clickers that was found to be the least useful was in the final examination review session. This observation is consistent with the work of others, who have found that the overuse of clickers may have poor results if the right niche is not found (Draper \& Brown, 2004). The examination reviews conducted may not have been a good application of clickers. Although clickers are useful for formative assessment in very large courses, where they help to improve student interactions, other methods are available both for formative assessment and for catalyzing student cooperation in smaller courses such as this. The application for which the clickers were thought to be most useful was in the discussion of controversial issues, as students could propose minority opinions without being singled out.

\section{Acknowledgements}

We would like to acknowledge those faculty and staff members at the University of Northern Colorado who have also taught this course for their generous sharing of suggestions and ideas: Carol Fortino, Teresa Higgins, Kimberly Pacheco, Richard Schwenz, Jerry Suits, Michael Taber, Courtney Willis, and Seth Willis. We would also like to acknowledge the efficient technology support provided by Lori Reinsvold, Mathematics and Science Teaching Institute. 


\section{References}

Ardac, D., \& Akaygün, S. (2004). Effectiveness of multimedia-based instruction that emphasizes molecular representations on students' understanding of chemical change. Journal of Research in Science Teaching, 41, 317-337.

Bryson, B. (2003). A Short History of Nearly Everything. London: Doubleday.

Cochran, K., \& Jones, L. L. (1997). The Subject Matter Knowledge of Preservice Science Teachers. In B. Fraser, \& K. Tobin (Eds.), International Handbook of Science Education (pp. 707-718). Kluwer: The Netherlands, 1998.

Crawford, B. A. (2000). Embracing the essence of inquiry: New roles for science teachers. Journal of Research in Science Teaching, 37(9), 916-937.

Davis, K. S., \& Falba, C. J. (2002). Integrating technology in elementary preservice teacher education: Orchestrating scientific inquiry in meaningful ways. Journal of Science Teacher Education, 13(4), 303-329.

DeBoer, George E. (1991). A History of Ideas in Science Education: Implications for Practice.

New York: Teachers College Press.

Derry, G. N. (1999). What Science Is and How It Works. Princeton, New Jersey: Princeton University Press.

Draper, S.W., \& Brown, M.I. (2004). Increased interactivity in lectures using an electronic voting system. Journal of Computer Assisted Learning, 20, 81-94.

Edelson, D. C., Gordin, D. N., \& Pea, R. D. (1999). Addressing the challenges of inquirybased learning through technology and curriculum design. The Journal of the Learning Sciences, 8(3\&4), 391-450.

Fagen, A., Crouch, C., \& Mazur, E. (2002). Peer instruction: results from a range of classrooms. Physics Teacher, 40, 206-209.

Ferk, V., Vrtacnik, M., Blejec, A., \& Gril, A. (2003). Students' understanding of molecular structure representations. International Journal of Science Education, 25(10), 1227-1245. Fleming, N.D., (1995). I'm different; not dumb. Modes of presentation (VARK) in the tertiary classroom. In A. Zelmer (Ed.), Research and Development in Higher Education, Proceedings of the 1995 Annual Conference of the Higher Education and Research Development Society of Australasia (HERDSA),HERDSA, Volume 18 (pp. 308 - 313). Flick, L. B., \& Lederman, N. G. (2006). Scientific Inquiry and the Nature of Science: Implications for Teaching, Learning and Teacher Education. Netherlands: Springer.

Fortino, C. (2003). From historical stories to hands-on labs. Colorado Science Convention, Denver, CO, Nov. 21.

Gabel, D. (2003). Enhancing the conceptual understanding of science. Educational HORIZONS, 81(2), 70-76.

Gitlin, A., Barlow, L., Burbank, M. D., Kauchak, D., \& Stevens, T. (1999). Pre-service teachers' thinking on research: implications for inquiry oriented teacher education. Teaching and Teacher Education, 15, 753-769.

Haefner, L. A., \& Zembal-Saul, C. (2004). Learning by doing? Prospective elementary 
teachers' developing understandings of scientific inquiry and science teaching and learning. International Journal of Science Education, 26(13), 1653-1674.

Howes, E. V. (2002). Learning to teach science for all in the elementary grades: What do preservice teachers bring? Journal of Research in Science Teaching, 39(9), 845-869. Interactive Clickers can increase student response. (2006). Curriculum Review, 45(4). Jones, L. L., Buckler, H., Cooper, N., \& Straushein, B. (1997). Preparing Preservice Chemistry Teachers for Constructivist Classrooms through Use of Authentic Activities. J. Chemical Education, 74, 787-788.

Jones, L. L., \& Smith, S. G. (1993). Multimedia Technology: A Catalyst for Change in Chemical Education. Pure and Applied Chemistry, 65, 245-249.

Kelly, R. M., \& Jones, L. L. (2007). Exploring how different features of animations of sodium chloride dissolving affect students' explanations. Journal of Science Education and Technology, 16(5), 413-429.

Kim, M. C., Hannafin, M. J., \& Bryan, L. A. (2007). Technology-enhanced inquiry tools in science education: An emerging pedagogical framework for classroom practice. Science Education, 91(6), 1010-1030.

Luera, G. R., \& Otto, C. A. (2005). Development and evaluation of an inquiry-based elementary science teacher education program reflecting current reform movements. Journal of Science Teacher Education, 16(3), 241-258.

MacArthur, J. R., \& Jones, L. L. (2008). A review of literature reports of clickers applicable to college chemistry classrooms. Chemistry Education Research and Practice, 9(3), 187-195. McDevitt, T. M., Troyer, R., Ambrosio, A. L., Heikkinen, H. W., \& Warren, E. (1995). Evaluating prospective elementary teachers' understanding of science and mathematics in a model pre-service program. Journal of Research in Science Teaching, 32(7), 749-775. Millar, R., \& Lubben, F. (1996), Knowledge and action: Students' understanding of the procedures of scientific enquiry. In G. Welfor, J. Osborne, \& P. Scott (Eds.), Research in Science Education in Europe (pp. 191-199). London: The Falmer Press.

Minner, D. D., Levy, A. J., \& Century, J. (2010). Inquiry-based science instruction-what is it and does it matter? Results from a research synthesis years 1984 to 2002. Journal of Research in Science Teaching, 47(4), 474-496.

National Research Council (200o). Inquiry and the Science Education Standards, National Research Council, 2000, Washington: National Academy Press. Retreived April, 19, 2011 from http://books.nap.edu/html/inquiry_addendum/.

Nelson, M. (2000). A case of preservice elementary teachers exploring, retelling, and reframing. Research in Science Education, 30(4), 417-433.

Newman, W. J., Abell, S. K., Hubbard, P. D., McDonald, J., Otaala, J., \& Martini, M. (2004). Dilemmas of teaching inquiry in elementary science methods. Journal of Science Teacher Education, 15(4), 257-279.

Novak, A. (1964). Scientific inquiry. Bioscience, 14, 25-28.

Oblinger, D. G., \& Oblinger, J. L. (Eds.) (2005). Educating the Net Generation, Educause. 
Retreived April, 19, 2011, from http://www.educause.edu/educatingthenetgen.

Sims, R. R., \& Sims, S. J. (1995). The Importance of Learning Styles. Westport, CT:

Greenwood Press.

Šimenc, M. (2008). The status of the subject in the classroom community of inquiry.

Theory and Research in Education, 6(3), 323-336.

Taber, M. R., \& Quadracci, K. (2006). Building geosciences vocabularies using a data visualization tool. In C. Manduca, \& D. Mogk (Eds.), Earth and Mind: How Geologists

Think and Learn about the Earth, Boulder. Colorado: The Geological Society of America. Trees, A. R., \& Jackson, M. H. (2007). The learning environment in clicker classrooms: student processes of learning and involvement in large university-level courses using student response systems. Learning Media and Technology, 32, 21-40.

Tuan, H-L., Chin, C-C., Tsai, C-C., \& Cheng, S-F. (2005). Investigating the effectiveness of inquiry instruction on the motivation of different learning styles students. International Journal of Science and Mathematics Education, 3(4), 541-566.

Windschitl, M. (2002). Inquiry projects in science teacher education: What can investigative experiences reveal about teacher thinking and eventual classroom practice? Science Teacher Education, 112-143. 


\section{Biographical note}

LoretTa L. Jones is Emeritus Professor of Chemistry at the University of Northern Colorado, US. She has a Ph.D. in physical chemistry and a D.A. in chemical education (University of Illinois at Chicago, 1979). In 2006 she chaired the American Chemical Society Chemical Education Division. She is a Fellow of the American Association for the Advancement of Science and the coauthor of chemistry textbooks and multimedia courseware. Her research focuses on helping students understand chemistry through visualization.

JAmes R. MacArthur is Visiting Assistant Professor of Chemistry at Adams State College, Colorado, US. He has an MS in chemical engineering (Colorado School of Mines, 2002) and a Ph.D. in chemical education (University of Northern Colorado, 2010). He has taught chemistry and physical science for 11 years. His research focuses on understanding student interactions in science courses and technologies that might facilitate these interactions.

Sevil Akaygün is Instructor of Chemical/Science Education at Boğaziçi University, Istanbul, Turkey. She taught high school chemistry and middle school science for 12 years. She has an MS in science education (Boğaziçi University, 2000), an MS in chemistry (University of Northern Colorado, 2008) and a Ph.D. in chemical education (University Northern Colorado, 2009). Her research interests are dynamic computer visualizations and how they are used in the learning and teaching of chemistry. 